http://spilplus.journals.ac.za/

111 \title{
THE THEOLOGIAN'S SEARCH FOR "MEANING": RESTRAINT OR
LIBERATION OF THE CREATIVE SPIRIT?
}

Gerrie Snyman, Department of Old Testament (Unisa)

\section{INTRODUCTION}

A few years ago, a standard nine pupil in the Western Transvaal wrote about her vision of being an adult. She dreamt of her future handsome, loving, caring, helping husband, the children they would have and the career she would follow. In describing her marriage, she said the following:

My wedding should take place at the sea-side. 1 want my marriage to start on the rocks.

It was an English essay by someone who was not quite conversant in the language. She obviously did not realise that what she said was actually the exact opposite, because a marriage on the rocks, is a marriage which has failed. But she obviously had something else in mind: Luke 6:48-49.

Luke 6 describes the firmness of a house built on rocks against one built on sand. To this girl the rocks were a metaphor of firmness and she did not consider wbat the sea does to a boat shipwrecking on the rocks. Although this little story is a jewel, it shows what people do when they have not acquired a literary competence which could direct them to read for metaphor, symbolism or allegory (cf Fowler 1986:175).

The Bible as literature is a legitimate use of language, but this is not the sole reason why the theologian should have linguistic knowledge. Theology as a scientific discipline is of a double linguistic nature:

- On the one hand, theologians are required to be skillful readers of the Bible in its original languages.

- On the other hand, in their interpretation of the Bible, theologians through the ages have developed metaphors to describe the symbolic universe of the religious belief systems they adhered to.

Theology not only concerns the learning of ancient foreign languages such as Creek, Hebrew and Aramaic, but also the manner in which people use contemporary language to express their beliefs. The concern should therefore not only be with the biblical text but aiso with the human need to use language to capture thought and to discharge emotional tensions (cf Di Pietro 1976:23).

The contention of this article is that a study of languages in the sense of linguistic criticism ${ }^{1}$, will make an enormous contribution to the practice of theology for several reasons. Words do not reflect reality neutrally. The moment they are used, they have already been interpreted, organised and classified in the discourse according to linguistic codes (Fowler 1986:27). These codes embody theories of how 
the world is organised in terms of world-view or ideology. But the use of language is not free. Language is conventional, thus shared by people. It is a social practice which is manifested in individuals (cf Fowler 1986:27). Very few theologians have realised the important role language plays in creating theological propositions ${ }^{2}$, because of a naive-sealist point of view about language and reference in language. Secondly, many theologians do not realise the important role people as recipients play in reading the Bible and in creating subsequent theological concepts. And thirdiy, because of the first two factors, theologians' own creativity in interpreting the biblical text is undermined.

To illustrate the problem of language in theology, the inadequacy of literal discourse to express religious belief will firstly be discussed. Because language is laden with values, theological propositions are created metaphors. Therefore, theologians as language users are coproducers of their (religious) reality. This is the second argument. If people are the part of the production of their reality, one way in which religious reality is created, is narrative. Therefore, in the last instance, the role of stories as expression of religious beliefs will be discussed.

\section{LITERAL DISCOURSE}

Theology as a cognitive act (cf Conradie 1990:20-29) holds the Bible as Glaubensquelle in high esteem. The Bible is used as the unicum principium cognoscendi. As a source from which a system of truths about God can be deduced and sistematised, the biblical text is regarded as a deposit of meaning of which the interpretation is fixed. Language is regarded as the representation of thought. Due to the correspondence drawn between language and thought, the reading of the Bible is a neutral ${ }^{3}$ act and done according to commen sense. If one knows how to read, one will inevitably read and understand what is written.

Because readers are not seen meaningfully relating to their historical and cultural environment in the cognitive act, reading is unproblematical. The non-recognition of readers' social embeddedness gives rise to, and is aiso supported by, naive realism. What is being read is not only regarded as a careful and accurate description of the author's mind, but it is also taken as a direct replica of that to which he referred (cf yan Huyssteen 1987:19-20). The Bible reader thus treats the biblical text as a closed reality in which his only task is to search for the meaning the author inscribed into the text once and for all.

The discourse of the biblical text is taken in its literal sense, whereby an immediacy of knowledge is presupposed. Judgment on what is read is taken to be immediate and independent (cf JN Vorster 1988:158). Therefore, a direct relationship exists between what is observed and the concept formed about it. Consequently, in biblical narratives, readers can draw a direcl correspondence between what has been written in the text and that to which it refers, as well as between the concept formed by 
them and the discourse in the text. What they observe, is not an idea of what is being referred to, but the event itself. Blumenberg (1964:10) calls this line of being referre "Realität der momentanen Evidenz", where readers completely ignore the empirical sphere in which they as readers stand, as well as that in which the authors of the text once stood. In what can be called a common sense realism, truth and reality converge in the moment of presentation in discourse.

The historical grammatical ${ }^{4}$ method is fully situated in this common sense realism. It seeks to interpret the text historically while accepting at face value the text as referring to actual events in history. The grammatical side of this method concerns the interpretation of the text in the original languages, namely Hebrew, Greek or Aramaic. The procedure entails a study of the individual words as determinants of the meaning of a sentence (cf Scheffler 1991:52-53). One should add that the utterances thus studied are only studied as utterances of an author and not as utterances understood by a community of readers. The dogmatic presupposition behind this approach is that the Bible is the word of God. With God being the author, the Bible cannot be anything else as is his word, universal and valid for all times and all situations.

The historical grammatical exegesis' most important contribution ${ }^{5}$ to the reading culture of the biblical text was the emphasis on the original languages ${ }^{6}$. And its most important weakness is the failure to realise that historical grammarians are, like the human biblical authors, children of their age. The effect of taking biblical discourse literally, is to give the Bible a privileged epistemological status in order to provide readers with absolute certainties.

The privileged epistemological position of the Bible coincides with its authority in matters of faith. God, regarded as the prime author (who merely used humans to record his words), cannot lie as human do. Every resistance falls away, no questions are asked, because everything in the Bible is true and one can only accept it. The only thing the authors could do, was to receive God's words and write them down. And the readers' task now is to listen and to obey. Any human creativity has become redundant. Where everything is taken in a literal sense, readers have the obligation to accept what is given to them ${ }^{7}$.

The nightmare any naive realistic theologian have to suffer is the undermining of certainties based on a naive realistic reception of the Bible. Theology as a cognitive act seeks to establish theological knowledge on a firm base, which is found in the biblical text. The historical grammatical method seeks a firm theological knowledge in the literal reading of that text. Consequently, the nightmare of any of these theologians would be having their firm base undermined. And this is exactly where linguistic criticism can play a useful role, namely in questioning the literal base of their theological enterprise. 
http://spilplus.journals.ac.za/

Taking the biblical discourse literally at all costs implies forgetting that language is very much a human creation and that theology is an interprelative event. Nol only is the discourse of the biblical text important, but also the context in which it is uttered and in which it is interpreted by other people. Furthermore, in religious documents language tends to be metaphorical in character because it expresses that which cannot be expressed in literal discourse (cf van Huyssteen 1986:161). As a figure of speech it enables one to view an unknown reality from the point of view of a known reality. Language is very flexible and efficiently conveys thought (cf Di Pietro 1976:2), although it is not sufficiently to draw a direct correspondence between word and thought. Even our calling the Bible the Word of God should be treated as metaphorical language, as Calvin did when he spoke of reading the Bible as if it is the Word of God8.

\section{READERS' ROLE IN CO-PRODUCING RELIGIOUS REALITY}

In theology, more attention should be paid to the interpretative activity of theology. Theology entails the creation of metaphors through which a religious community can order their experience of an ultimate reality. Language plays no minimal role in the entire process, because it is through language that people create the world they live in.

Through the medium of language readers are able to grasp a world in a text and experience it as real. In order to obtain this experience, readers should be conversant with the language employed in the text. When that is impossible, a double strangeness could set in regarding the text because of a strange language and, most of the time, an alien culture embodied in that strange language. The biblical text confronts its readers with a similar strangeness, which readers try to overcome by studying biblical languages and the cultures embodied in them. But because the double strangeness of the biblical text is difficult to overcome even with knowledge of the language and culture, the plausibility of the world of the biblical text is difficult to experience, even to the point that it is seriously questioned.

One way to overcome this difficulty, instead of ignoring it, is to treat theology - in the sense of an interpretative event - as a form of dialogue (cf Conradie 1990:58). Reading is not a passive absorption of the discourse, but "appropriated" through conversation or dialogue. Berger (1987:29) regards human participation in conversation as the only ontological base for language: language exists because people employ it. Through the medium of language (as long as the conversation takes place) readers can grasp a world in a text and experience it, but as soon as the conversation stops or changes, it becomes difficult to grasp or experience that world.

The strangeness of the biblical text is caused by the lack of a proper conversation. Biblical Hebrew and classical Greek no longer exist in order to sustain a particular world view. The very strangeness, and the subsequent break in communication 
provide sufficient evidence that a literal reception of biblical discourse is doing a provide suce to the biblical text. But despite a break in communication, readers who associate the Bible with metaphorical language and transcendency, keep the Bible alive; each time they read the text, they revive it by attaching new meaning to it.

Readers revive the text through a one-sided human dialogue and not a full scale dialogue between the author of the text and its readers, an impression one may gain from Gadamer (1986:368-385) ${ }^{9}$. The conversation partner is invisible to the readers, and one wonders whether this invisible partner is not a construct from the readers themselves, so that the questions posed to the readers are actually questions the readers posed to themselves, via the text.

The text does not have the character of a question, it only becomes a question to those who asks questions (Pannenberg 1970:123, Jauß 1982:398). In a textual dialogue one of the partners is represented in the text and can therefore not speak directly or immediately to the readers (cf Jau B 1987a:12) as presupposed by the cognitive model of theology. The biblical text's strangeness strengthens this impossibility and causes the text to 'beg for an explanation'.

The posing of questions in a conversation is never innocent or neutral. They are posed from the participants' horizons of experience. Confronted by a text, readers bring with them a whole spectrum of ideas and concepts that determine their point of view. But it is not only the readers that are socially embedded. The text is, too. The text's social context requires from the readers to ascertain those questions to which the text initially was an answer. Furthermore, the readers' own social context will force them to formulate questions the text did not initially answer, but could, in a later situation.

A text comes into existence because of a need to be answered. In other words, a particular exigence calls the discourse into existence (cf Bitzer 1968:2). As a response to a situation of a certain kind, the djscourse in the text is prescribed by the situation which demands a certain observation to be made. The picture thus formed is controlled by the situation in the same way that a question controls the answer (cf Bitzer 1968:6).

The cognitive model of theology, as exemplified by the historical grammatical method of exegesis, presupposes a conversation between readers and God. The text, being God's word, serves as a substitute for his voice. There is nothing that can dissupt that conversation, not even the cultural remoteness of the biblical text or its linguistic strangeness. Readers regard themselves as part of the original rhetorical situation. Subsequently, the discourse directly provides the readers with an order within which they can make sense of experience and within which their lives have meaning 10 . 
http://spilplus.journals.ac.za/

116

Bitzer (1968:13) leaves room for a universal rhetorical situation which demands a universal response. That response is found in a body of rhetorical literature which exists as rhetorical responses because they address situations which persist. But there is a difference between a recurring situation and the same rhetorical situation which is believed to be continuing. In communicating biblical texts, the latter is simply impossible because of the breakdown of conversation. A recurring situation on the other hand is never exactly the same and the response needs adjustments, in order to suit the immediate needs of the exigence giving rise to the rhetorical situation.

Language serves as a vehicle for rhetorical responses to situations inviting discourse. The question readers should ask is why a specific utterance is more appropriate to the context than any other utterance. The context shapes the response. And the response, which is a created new textual world, is embedded in the ideologies, social values and relations of the world of the author of the text (cf Vorster 1991:43). A realisation of the difference between these and the values, ideologies and relations of later readers' world, causes a disruption in the conversation, so that the textual reality can never be taken for granted.

Language creates the world in which the users of that language live (Berger 1987:29) because it orders the experience of the people and provides an order of relationships. In this manner, language constitutes what Berger calls an "objective" reality in the sense that certain rules should be obeyed in order to communicate effectively in a particular language, whereas the subjective reality concerns the conversation (Berger 1987:26). The objective reality is the everyday language, which is shared by a group of people, and which provides order for their experience. In linguistic terms, this objective reality could be called the convention of language within a particular society.

Although everyday language provides a society with order, the world that is created through that language, is extremely precarious and in need of constant legitimation according to Berger (1987:41). Religion is one of the instruments of legitimation whereby the humanly defined reality is related to an ultimate sacred reality. The order human beings have bestowed ex nihilo on their world through language is transferred to a sphere where that order is regarded as having been in existence from the beginning of time. To put it bluntly, an analogy is created between the human world created through language and a sacred or ultimate world, so that the humanly created world reflects the divine structure. In ancient religions sexual intercourse mimed the creation of the universe: "Representation of human meanings becomes mimesis of divine mysteries" (Berger 1987:47).

Language plays a significant role in the legitimation process. The experience of something mysterious, or bigger than humankind itself, requires a language in which the experience could be described. The language thus required is highly symbolical. 
Language, referring to the reality people experience in everyday life and rooted in the common sense knowledge of the society, is capable of transcending the reality of eyeryday life. Language can actualise an entire world at any moment: it is not only capable of presenting people physically absent or in the remembered past (Berger 1976:55), but can soar into regions that are not available to everyday experience, so that they are located in one reality but refer to another (symbolic) reality.

The symbolic reality, also called a symbolic universe, refers to realities other than those of everyday experience (Berger 1987:113). The symbolic reality cannot be experienced in everyday life, but it seeks to integrate the social institutions and their order into an all-embracing frame of reference. All human experience is conceived of as taking place within this frame of reference.

A symbolic universe is not a reality in the sense of the reality of everyday experience. It is a created reality, created by a linguistic structure in order to bring the experience of the otherness under a name. Behind the physical appearance of the world is an ultimate ground, a larger world, an environment transcending our conceptions of reality which reassure our confidence in life.

Haught (1990:170) refers to the experience of mystery which religions insists on giving a name. One example is the conception of God in the three book or theist religions that posits the existence of a transcendent God as the ultimate basis of reality. Theists have the conviction there is someone that makes the universe trustworthy and that renders the world and human existence meaningful (cf Haught 1990:153). "God" is one of the countless names people have used to name or describe their base for believing in reality and in life. The Hebrews named Him Yahweh ( $(\mathrm{am}$ what I am), the ancient Greeks referred to him as Zeus, and the later Greeks called Him Kurios (master), the Hindus refer to God as Brahman, the Islam as Allah, the Buddhists as Dharma, etc.

The concept of God is determined by the world and culture created by a community's language. To those who do not share the same religious tradition, other traditions' stories of God seem lifeless and meaningless or even false, because religion's function as a metaphor to reaffirm the ultimate source of trust, is undervalued. This ultimate reality is beyond human control, although people use language to express a symbolic consciousness which sees, beyond the ordinariness of things, some mystery (cf Haught 1990:156). Even in one religion, the concept of God can change according to different historical periods; for example, in Samuel God is made responsible for David's census whereas in Chronicles the Satan is made responsible. When Samuel was written, people attributed evil to God, whereas in post-exilic times evil was attributed to Satan.

How are these symbolic universes constituted? Berger's (1987:22) suggestion of language as a human product presenting itself as an objective reality, refers to the 
presence of language as a ready and collectively recognised universe of discourse within which individuals may understand each other and themselves. Although Berger may leave the impression that language is a finished product (with which I disagree), the very existence of conventional codes in language that are common sense and common place amongst its users is of importance. This common sense is not natural but established by social convention (cr Fowler 1986:29). One may also call it an "official language" which comprises of meanings encoded in language by a community. These meanings are a community's store of established knowledge, which one learns as a child. In its language each community encodes knowledge that is peculiar to that community and different from other communities (Fowler 1986:21). Thus, one speaks in the language of the society through which one creates the reality. This language is normally characterised by structures and meanings authorised by the dominant interest groups of the community (Fowler 1986:29)11.

\section{THE ROLE OF STORIES}

One way in which the religious reality is brought home, is by the telling of stories. Narrative is of the essence of the Bible, since people use the narrative mode to interpret the world (cf Schneidau 1986:136).

According to White ${ }^{12}$ (1980a:5) to narsate is past of human nature. Narrativization is the central function of the human mind and has the power to make people moral human beings (White 1980b:795, 797) A narrative is "a metacode, a human universal on the basis of which transcultural messages about the nature of a shared reality can be transmitted." Between our experience of the world and our efforts to verbalise that experience, "narrative 'ceaselessly substitutes meaning for the straightforward copy of the events recounted." (White 1980:6, with reference to Roland Barthes).

The telling of stories about the cosmic reality is a legitimation of the social order and a reassurance against the threat of disorder (cf Berger 1987:36, Haught $1990: 150)$. A very good example is the stories about the origin of the world. Haught (1990:150) says there is something consoling and solidifying about the knowledge of origins. These stories are about realities unknown to everyday life and the story about God and the origin of humankind provides some light in the darkness of people's existence. In the process, the story thus told depicts a reality that people can grasp and relate to their everyday existence, although the proposed reality is a world constructed with symbols. Order is necessary for living in a chaotic world: "Knowing the beginnings of things is one way of keeping out the terrifying indefiniteness of the universe" (cf Haught 1990:152).

Several stories about the origin of the world exists. A very popular one amongst our people is the first three chapters of Genesis, which show how the world was conceived and why things got into the sorry shape they are in at this stage. But this 


\section{http://spilplus.journals.ac.za/}

119

story is not unique, since it borrowed elements from other creation stories in the region in which it was initially composed. One example is the enuma elish that tells us how the struggle between chaos and order began and how order eventually prevailed.

The Bible can be defined as a story with Goo as the prime actor and speaker The Bers 1987:15). God's story has been constructed by human authors' retigious and creative imagination. It is a story that is still continuously being constructed by people when they themselves read the verbal structure in the form of a prose narrative discourse that purports to be a model of the structure of people's past experience of God. The point is that the ultimate dimension of the Bible is not the verbal structure in the text, but the Gestalt readers form of it in the reading process. The Gestalt is a performance by readers on the basis of the verbal structure, their knowledge of the exigence that necessitated that structure and the rhetorical situation in which they find themselves and to which the text may provide an answer, if the text stirs up resonances of experience in the readers. In reading the biblical text readers are able to interpret their own experience of God in daily life. With their mental faculty they are able to form a picture of what God is like. It is an act of imagination, a narrative by which the unspeakable is acted out in the human mind.

In literature, language is used creatively in order to communicate experience. Literature is a verbal structure in the form of discourse (narrative or otherwise) aimed at creating new knowledge (Fowler 1986:14). Language is a central part of the social process. The meanings of words in a language as mere abstractions are the community's store of established knowledge (Fowler 1986:19). In other words, the language is a!ready ideologically encoded. When one uses words in a verbal structure, one does not consciously wrap them in value-laden language (Fowler 1991:41). The presentation of a verbal structure is habitual and conventional as much as it is deliberate and controlled. The values have already been inscribed into the language, independent of the creator of a verbal structure. It is not so much a case of an author constituting discourse as of the discourse constituting the author.

In the case of value-laden language, the readers know in advance the discourse and its meanings. The discourse brings predictively relevant mental models that the readers are to confirm during the reading process. The author and the readers should share a discursive competence (Fowler 1991:44) which helps them to negotiate the significance of the text around the stipulations of the discourse in question. In other words, the discourse cues to the readers a certain interpretation, and it depends on the readers whether they recognise those cues.

A creator of a verbal structure has little control over the values and beliefs which are found in language. Readers are not without power, because they read into the text the ideology which shapes an author's presentation of reality (Fowler 1991:46). But this language value laden with ideology has to be translated into personal 
thoughts. An author should translate the society's vocabulary into a style appropriate for interpersonal communication. There are two components to remember: on the one hand, any verbal structure is structured from some ideological point of view. On the other hand, these structures have some statemen to make and often work through implied propositions or presuppositions (Fowler 1991:85).

\section{CONCLUSION}

Hayden White (White \& Manuel 1978:) speaks of the myth of literalness, especially regarding verbal propositions whose referents exist in the historical past. In this case, as in the Bible, the verbal propositions about a particular thing in the past refers the readers to an entity they can only know through other verbal propositions. The royal story in the Books of Samuel and Kings can be verified by Chronicles and when one can objectify them, the sources referred to in these books. However, these verbal propositions come to the reader clothed in an ideologically laden language, which makes it impossible to treat the propositions as literal discourse. A "demythologising" process should be embarked upon in order to ascertain what the text wanted to say to a group of people in a particular situation. Similarly, one's own language use is value laden and coloured with ideologies or world-views. For this very reason different readers will generate different meaning when reading the same text. Theologians should realise that they will differ from other theologians, not because they themselves have the correct reading of a text, but because of the language they employ and because the situation for which they read a text, differs from society to society and from time to time.

I have tried to theorise about the sole of language in theology, with emphasis on readers of the biblical texts. Practicing theology is more than merely reading the tex in a literal way. The use of language in discourse makes it imperative to read any ancient text within its social context, while at the same time recognising the readers own social context and situation that demand an explanation.

\section{ENDNOTES}

The article follows Fowler's definition of critical linguistics: "an enquiry into the relations between signs, meanings and the social and historical conditions which govern the semiotic structure of discourse" (cI Fowler 1991:5).

2Van Huysstecn (1986) drew theologians' attention to the mctaphorical nature of theological propositions. His emphasis on language made it clear that language use should never be absolutised or ideologised in the sense pcople like to absolutise biblical metaphors in matters of doctrine. Any religious metaphor is provisional and open (1986:168).

${ }^{3}$ Conradie (1990:27) regards this model as an cffort to guarantee the objectivity of theologiocal propositions against subjectivity. Believers are thought to obtain "objective" knowledge about God.

4The name was used in 1788 by $\mathrm{Karl} \mathrm{Kcil}$ in his book De histarica libronem sacronum interpretatione 


\section{http://spilplus.journals.ac.za/}

eitsqie necessioate. Terry (1967:203) views the historical-grammatical excgesis as an interpretation of
the language cmployed by the author according to grammatical rules and the historical facts: "The
special laws of grammar, agreeably to which the sacred writers employed language, were the result of
their peculiar circumstances; and history alone throws us back into lincse circumstances." To Kaiser
(1981:88) granmatical refers to the most simple and dircet meaning of a word, whereas historical
refers to the meaning obtained by historical clements, such as the circumstances of the author.

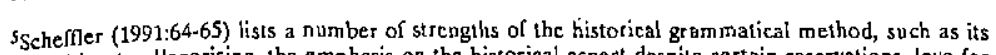
opposition to allegorising, the emphasis on the historical aspect despile certain reservations, love for opposition the the universalising tendency. However, the nethod's strengths also appears to be its the text and in order to communicate at all costs, readers fend to allegorise, historical problems are weaknesses: In the universatity of mcaning frequently results in forced re adings, dogmatic premises play an important role and the times of the origins of the biblical texts do not bother the exegetes.

${ }^{6} T$ The emphasis on the original languages was a prime reason for scholars to study Hebrew, Aramaic ${ }^{b}$ The emp Greek. The emphasis on the original languages comes from the time of the Reformation that was and Greek. The enphasis on the original languages comes from the time of the Reformation that was influenced by the Renaissance call to go back to the origins. The Reformers formulated their view of Sola Scriptura as the sole source for theology against the predominant Roman-Catholic view of the
Bible and tradition. Given the Renaissance's high esteem for the original languages and original documents, the Reformers found the OId Testament's origins in some Hebrew text that was available at that time.

7Placo's problem with human authors in contrast with the gods was that gods could not lie, they were

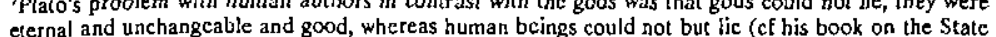
eternal and unchangeable and good, whereas human beings could not but inc (ct his book on the State
Politeias, 11,377, De Win, 1980 and Shorey, 1938:65). Because the supernatural realm was free from Politeias, ll,37, De Win, 1980 and Shorey, $1938: 65$. Because the supernatural realm was free from
deception, gods could nol lie. The "lies" people told in stories gave a false impression of the gods deception, gods could nol lie. The "lies" people told in stories gave a false impression of the gods
because of the lack of (a clear) correspondence between the way the gods were depicted and what they were really like. To Plato they were portrayed too humanly, and sometimes good as well as cvil werc atrributed to them. No deceptive picture of the gods could be tolesaled and it did not bring about any piety.

BInst. vii.1: asci vivae ipsae Dei voces illic exandirentur. The Bible is read as if it is the living voice of God. The biblical text, as any olher tcxt, has no closed reality or a meaning put there once and for all by someone. It is the readers who attach meaning to the biblical text according to the experience by someone. It is the readers who attach meaning to the biblical text according to the experience
evoked by the reading process. If readers regard the Bible as somcthing special, associatc it with metaphorical langunge and transcendency, and treat il as a religious text, thesc attitudes bear witness to a particular type of association with the Bible.

II a normal dialoguc, there are two equal partners who try to arrive at a common point through an exchange of verbalised thoughts. If they share the same language, they can eventualify arrive at some understanding. If the language they cmploy share the same ideology, the possibility of understanding will be cven greatcr. In applying this notion of conversalion to lhe reading of texts, Gadamer feels will be cven greatcr. In applying this notion of
obliged to let the text pul questions to the reader.

${ }^{10}$ Berger (1976:36) snys that to live in the world means to impose a meaningful order upon reality. Everyday language provides one with an order wilhin which one can make sense of experience and within which life has mcaning (Berger 1976:36). The reality of everyday life is shared with others. These significant others help to sustain the rcality to the effect that one can speak of a certain common sense knowiedge about the shared reality. Berger (1976.37) defines it as knowledge one shares with others in the normal self-evident roulines of everyday life. The reality is taken for granted and does not require verification. Thus, the reality appears unproblematical until the conversation is disrupted.

${ }^{11}$ These meanings are nowadays legitimated by TV, newspapers, books, advertiscments, films. However, most of the time, a language is loaded in favour of the political and economic interests that legitimate them. Language is a tool to preserve the prevailing order. 
http://spilplus.journals.ac.za/

${ }^{12}$ White concentrates his attention on historicsi works. He defines a historical work as a verbal structure in the form of a narrative prose discourse that purports to be a model, or icon, of past structures and processes in the interest of cxplaining what they were representing (White 1973:2). Historical discourse is regarded as a verbal artelact serving as a model or icon of nonverbal strucrurcs and processes (White \& Manuel 1978:6). 
http://spilplus.journals.ac.za/

\section{WORKS CONSULTED}

Berger, PL 1987. The social reality of religion. Penguin Bnoks: Harmondsworth Berger, PL
Berger, PL and Luckmann, T 1976. The sociol constriction of reality. A treatise in tise sociology af
knowledge. Penguin Books: Harmontisworth.

knowledge. Penguin Books. Harmontisworth.
. The rhetorical situation, Philosopity and R/setoric 1,1-14.

Bitzer, LF 1968. The rhetorical situation, Philosophy and Rhelonic 1,1-14. Blumenberg, H 1964. Wir klichkeitsbegrilf und Möglichke
Nochahinumg urd Ihision, 9-27. Eidos Verlag: Münclien.

Bosman, HL, Gous, IGP \& Spangenberg, IJJ 1991. Phitocrats and patipers. Weatth and povery in the Old Testantent. Van Schaik: Pretoria.

Conradic, EM 1990. Modellc van teologie as handeling. Scripntira S6:2-69.

De Win, X 1980. Plaio. Vetzanicld Werk, Derde deel: Alcibiades 1, De Sial, De Staglsman, Critiar. Ambo: Baarn.

Di Pietro, RJ 1976. Langrage as himan creation. The Sirst Andrew W Mellon Lecture. Georgetown Universily Press, Washington D.C.

Universily Press, Washington D.C.
Fowler, R 1986 . Linguistic criticism. Oxfard Universily Press: Oxford.

Fowler, R 1986. Linguistic criticism. Oxford Universily Psess: Oxford.
Fowler, R 1991. Language in the news. Discourse and ideology it tite press. Routledge: Londen.

Gadamer, H 1986. Wohricit tind Mediode: Gnindzilge einer philosophischen Hemtenettik. JCB Mohr: Tübingen.

Haught, JF 1990. What is religion? An introducrion. Pautist Press: Mahwah.

$\mathrm{JauB}, \mathrm{H}-\mathrm{R}$ 1982. disthetische Erohning tud hiterarische Hermeneutik. Suhrkamp: Franklurt an Main.

JauB, H-R 1987. The book of Jomah. A paradignt of the "herntenertics of strangeness". University of Minnesota: Mirneapolis.

Kaiser, W C 1981. Toward an exegetical titeology. Biblical exegesis for preaching and reaching. Baker Book House: Grand Rapids.

Pannenberg, W 1970. Basic qitestions in theology. SPCK: London

Sanders, JA 1987. From socred story to sacred tert. Fortress Press: Philadelphia.

Scheffler, E 1991. What does God's word refer to? Historical-grammatical exegesis, in Bosman, Gous \& Spangenberg 1991:52-6.

Schneidau, HN 1986. Biblical narrative and modern consciousness, in McConnel, FD (ed) The Bible and the narrative tradition, 1986:132-150. Oxford university Press: New York.

Shorey, P 1938. Platonism. Ancient and moden. University of California Press: Berkeley.

Terry, MS 1967. Biblical hemeneutics. Zondervan Publishing House: Grand Rapids.

Van Huyssieen, W 1986. Teologic as krticse geloofsverantwoording. Pretoria: RGN.

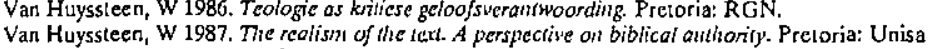

Van Huyssteen, W 1987. The reolisn of the tert. A perspective on biblical autionity. Preloria: Unisa,
Vorster, JN 1988. The usc of Scripture in fundamentalisn, in Moulon, J, Van Aarde, AG \& Vorster,

Vorster, JN 1988. The usc of Scriplure in fundamentalisn, in Moulon, J, Van Aarde, AG \& Vorster,
WS (eds) Paradigns ond progress in theology: HRSC Stidies in Researcit Meltodology Vol '5: 355-175. HRSC: Pretoria.

Vorsler, JN 1991. The rhetorical situation of the letler to the Romans - an interactional approach. D. Div.-thesis, University of Preloria.

White, $\mathrm{H} 1980 \mathrm{a}$. The value of narrativity in the representation of reality. Critical Inquiry 7:5-27.

White, $\mathrm{H} 1980 \mathrm{~b}$. Critical response. The narralivization of real events. Critical liguiry 7:793-798.

White, H \& Manuel, FE 1978. Theories of history. Papers read at a Clark Library Seminar. William Andrews Clark Memorial Library, University of California, Los Angeles. 